\title{
Possibility of power generation control in small hydro installations for a period of several days
}

ABSTRACT: The article discusses the importance of small hydro power plants in the Polish power system and defines the legal conditions for the operation of small hydro power plants. The phenomena occurring in the hydrological system of small hydro power plants and their impact on the natural environment were analyzed.

An analysis of phenomena occurring in the hydrological system and the activity of small hydro power plants that are operating on the Radunia River helped us identify relations between different types of power plants working in cascades and possibilities of power generation control in period of several days.

The above-mentioned analysis has been used in the development of a mathematical model of a hydroelectric plant and cascades of hydroelectric plants. The numerical simulations carried out concerned both the self-operating power plant and a cascade of two identical objects of this type. There is a possibility for small hydro power plant to run as a base load power plant and during periods of high demand as well (peak demand or unexpected loss of generation in the power system). A single hydroelectric power plant can deal with varying peak load demands while adding a second stage increase those abilities. A cascade of reservoir hydropower plants has a much greater ability to store energy and give it back in time. In addition, the existence of a second power plant equipped with a surge reservoir allows for a significant reduction in the amplitude of flows in the river below the cascade, which will reduce the negative impact of the cascade on the environment.

KEYWORDS: small hydro, water turbine, renewable energy sources, generation control

\footnotetext{
${ }^{1}$ Institute of Electrical Power Engineering, Warsaw University of Technology, Poland; e-mail: dariusz.baczynski@ ee.pw.edu.pl,kosinsk1@ee.pw.edu.pl
} 


\section{Introduction}

In the face of increasing climate change and increasing prices of fossil fuels, distributed generation (DG) and renewable energy sources (RES) are becoming increasingly popular in Europe. The highest dynamics of development and the largest increase in power have been recorded for many years in wind and solar energy. These sources are strongly dependent on atmospheric conditions, which destabilizes the power system. In order to prevent this, energy storage systems are used. This article is an attempt to indicate the possibility of using small hydropower plants as controllable sources that also provide an energy storage capacity.

Hydropower installations can be classified by the size of the power output. There is no international consensus for setting the size threshold between small and large hydropower. In Europe, small hydro power plant capacities are generally smaller than $5 \mathrm{MW}$. Power generation in small hydro power plants is one of the most economically viable methods of producing electricity.

In the twentieth century, the construction of hydroelectric power plants was usually associated with the construction of large dams that cross the riverbed. The construction of such a dam impedes the natural running of the river and creates reservoirs that significantly change the ecosystem. In order to obtain a high water level, it is necessary to flood huge parts of river valleys, which results in the resettlement of the local populations and the probable extermination of local wildlife. These reservoirs, however, help to protect the areas below against floods. Rivers are becoming navigable through the equalization of flows. These reservoirs are also storage of fresh water for agriculture and industry.

At present different small hydro technologies and innovations are being developed. SHP mainly use buildings and equipment left after old industrial plants equipped with water engines. Therefore, they do not create new water reservoirs. They have a positive influence on the groundwater levels and water retention, calm waters of the river and reduce the erosion of the river banks. Fish passages (fish ladders) help protect fish populations and their natural habitat (Hoffmann 1992).

\subsection{Hydrological characteristics of Poland}

The manner of river basin management is closely related to the climatic and geological conditions in their area. Poland is a state with a small gradient of terrain height, small precipitation and a relatively high permeability of land cover. The country's hydrographic system is dominated by lowland rivers, so it is not possible to build high gross head power plants. The energy potential of Polish rivers is also limited from the point of view of flows. The most commonly quoted analyses include the following values of hydropower natural resources (Korczak 2011): 
$\checkmark E_{\dot{s} r}=19900 \mathrm{GWh} / \mathrm{ann}$. - Polish Academy of Sciences study, 1956,

$\checkmark E_{\dot{s} r}=29000 \mathrm{GWh} / \mathrm{ann} .-$ Polish Academy of Sciences study, 1958,

$\checkmark E_{s r}=23600 \mathrm{GWh} / \mathrm{ann}$. - Cadaster of water technical resources in Poland, Hoffman, 1961.

The data listed above are estimates of the theoretical values of Poland's hydroelectric resources. The technical (net) potential is however much smaller, because it is reduced in relation to the gross potential by the efficiency of the devices used. Current estimates refer to the total technical resources of Polish rivers at around 12,000 GWh/ann., which account for less than 52\% of the theoretical potential (Field study... 2005). However, they do not take into account the potential contained in small watercourses or their sections with a potential lower than $100 \mathrm{~kW} / \mathrm{km}$. This means that the part concerning micro hydropower has been omitted. The report of the European Small Hydropower Association (Small... 2004) contains estimates of the potential of hydropower, which can be managed by micro-hydroelectric power plants (Table 1).

TABLE 1. Potential SHP capacity in Poland

TABELA 1. Krajowy potencjał hydroenergetyczny MEW

\begin{tabular}{|c|c|c|c|c|}
\hline & \multirow{2}{*}{$\begin{array}{l}\text { Potential SHP capacity } \\
\text { [GWh/ann.] }\end{array}$} & \multicolumn{2}{|c|}{ Annual generation } & \multirow[t]{2}{*}{ Power } \\
\hline & & {$[\%]$} & [MW] & \\
\hline \multicolumn{2}{|c|}{ Theoretical capacity potential } & 13,400 & 100.0 & - \\
\hline \multicolumn{2}{|c|}{ Technical capacity potential } & 5,050 & 37.7 & - \\
\hline \multirow{4}{*}{$\begin{array}{l}\text { Economically } \\
\text { feasible potential }\end{array}$} & Total & 2,500 & 26.1 & 605.0 \\
\hline & Installed capacity & 962 & 38.5 & 233.0 \\
\hline & Untapped potential & 1,538 & 61.5 & 372.0 \\
\hline & $\begin{array}{l}\text { Untapped potential } \\
\text { (taking ecological conditions into account) }\end{array}$ & 1,500 & 60.0 & 310.0 \\
\hline
\end{tabular}

Source: (Field study... 2005).

\subsection{Legal conditions for small hydro activity in Poland}

The current provisions of the national law are primarily aimed at implementing the recommendations of the Water Framework Directive (WFD - Directive 2000/60/EC). It established a framework for the protection of inland surface waters, which:

$\downarrow$ protects the condition of aquatic ecosystems,

$\downarrow$ promotes sustainable water use,

$\checkmark$ contributes to reducing the effects of floods and droughts.

In Article 4, the WFD provides the following main environmental objectives for surface waters:

$\checkmark$ prevention of the deterioration of all surface waters,

$\checkmark$ improvement of all artificially and heavily modified water bodies in order to achieve good ecological potential and good chemical status, 
$\checkmark$ implementing measures necessary to reduce pollution with priority substances (i.e. substances that should be eliminated from waters) and eliminate emissions of hazardous substances.

In the WFD, however, it was found that EU member states may designate a part of the surface water as artificially or heavily changed when changes necessary to achieve a good ecological status would have a significant negative impact on, among others, energy generation.

WFD has been incorporated into Polish legislation primarily through the Water Law Act and through the Environmental Protection Law. They define the principles of water resources management, including in order to create conditions for the energetic use of water. One of the most important instruments serving this purpose are water and legal permits and a system of fees for the use of water

The use of waters has been divided into general, ordinary and special use. The latter group includes, among others, the use of water for energy purposes, which means that hydroelectric plants must obtain a water permit. It is issued for a definite period (for a period not longer than 20 years). It contains information on the purpose and scope of the use of water, operating conditions bearing in mind, among others, the protection of environmental resources, interests of the population and the economy.

These include:

$\downarrow$ the amount of water taken, including the maximum amount of $\mathrm{m}^{3} / \mathrm{h}$ and the average amount of $\mathrm{m}^{3} /$ day and the maximum amount $\mathrm{of}^{3} /$ year,

$\downarrow$ characteristic elevation ordinates,

$\checkmark$ characteristic flows,

$\checkmark$ hydropower operation modes,

$\downarrow$ limitations resulting from the need to maintain the inviolable flow,

$\downarrow$ the procedure to be followed during the start-up, stoppage or breakdown of relevant equipment and the maximum permissible duration of these conditions.

It is possible to refuse to issue the abovementioned document, when the project of water use for hydroelectric purposes does not ensure the utilization of hydroelectric potential in a technically and economically justified way.

\subsection{Hydroelectric power plants in Poland}

The technical resources for river basins of individual rivers are respectively for: Vistula $77.6 \%$, Oder $-20.1 \%$ and the rivers of the Przymorze area (littoral zone) $-2.3 \%$. The aforementioned potential of the Polish rivers is currently only used in approx. $16 \%$, while in many other EU countries its use is even over $80 \%$ (Water... 2005). The register maintained by the President of the Energy Regulatory Office in Poland currently contains 761 hydropower installations with a total installed capacity of over 993.994 MW. However, it should be noted that the vast majority of power comes from large power plants owned by large energy groups. In the case of non-professional energy producers, energy comes almost exclusively from small conventional and run-of-the-river power plants. 
The total share of hydroelectric power plants in the production of electricity in Poland is small and is around only $3 \%$. Hydroelectric power stations, however, play an important role in stabilizing the operation of the National Power System thanks to their ability to immediately start up and ramp up their generating capacities. At the same time, they reduce the momentary power fluctuations and are suitable for use at peak demand. An additional advantage of SHP is the fact that they are connected to the power grid at a low or medium voltage level, which limits the transmission of energy over long distances, thus preventing transmission losses and reducing the load on the transmission networks. It should be remembered, however, that the work of small hydro is much more dependent on the hydrological conditions of the river than large hydropower plants with retention reservoirs.

Prospects for the development of hydropower are associated primarily with the modernization of existing power plants and the construction of new SHPs - both on previously unused watercourses and based on existing damming objects. The construction of new hydro power plants should accompany investments aimed at flood protection, counteracting the effects of drought and water supply. This will allow for the full use of the hydro-energy potential. The National Water Management Authority estimates that there are about 2,000 potential locations in Poland for the new SHPs (Proposal... 2010). For the purposes of the European Union project - RESTOR Hydro, an inventory of damming and past water-based facilities (inactive and ruined waterwheels driving mills, sawmil1s, etc.) was carried out in the past. Of the approximately 8,000 different types of hydroelectric installations that operated in Poland in the 1930s, about 6,000 are potentially re-usable for energy production (Restor... 2017). The utilization of the energy potential of currently unused hydrotechnical facilities allows for economically viable energy production in small renewable energy sources that can contribute to the local improvement of water relations (Water... 2005).

The basis for all considerations and analyses regarding the use of rivers is to assess the size and variability of their resources. Hydrological relations in river basins and watercourses determine flow characteristics determined on the basis of long-term observation sequences. The flow rate can be determined by measuring the height of the water stream above the weir. The long observation time allows the flow intensity, seasonal and annual fluctuations in medium, dry and wet years to be determined (Korczak 2011).

The main natural factors affecting the variability of flow rates are, among others:

$\downarrow$ river sources (including groundwater falls, lakes),

$\checkmark$ landform,

$\checkmark$ the dominant type of land in the river basin,

$\downarrow$ rainfall during the year.

The maximum hydropower power output is mostly dependent on how much head and flow is available at the site and the efficiency of individual power plant components (mainly turbine, gear and generator). Small hydropower plants are mainly run-of-the-river power plants that do not have a large retention reservoir, which could be used to regulate the flow of the power plant. (Matuszek 2005) The turbine is constructed for an optimal flow of water. The lower or higher inflow of water may reduce electricity output per unit of water. Depending on the hydrogeological conditions, very different SHP construction solutions are used. 


\section{Analysis of selected group of Small Hydropower Plants}

\subsection{Description of the analyzed SHP group}

The research object, on the basis of which the power generation control analysis was carried out, is a set of nine small hydropower plants located on the Radunia River in the Pomeranian region. The main power plants were built between 1910 and 1937 and were modernized several times. Their construction was commissioned by various legal entities, and the construction elements were made on the basis of different designs.

TABLE 2. Basic data of Radunia SHP

TABELA 2. Podstawowe dane MEW na Raduni

\begin{tabular}{|c|c|c|c|c|c|c|c|c|}
\hline Name & SHP type & $\begin{array}{l}\text { Type of } \\
\text { turbine }\end{array}$ & $\begin{array}{l}\text { Number } \\
\text { of gen. }\end{array}$ & $\begin{array}{c}\text { Nominal } \\
\text { Capacity } \\
{[\mathrm{kW}]}\end{array}$ & $\begin{array}{c}\text { Max } \\
\text { flow } \\
{\left[\mathrm{m}^{3 / s}\right]}\end{array}$ & $\begin{array}{l}\text { Total } \\
\text { capacity } \\
{[\mathrm{kW}]}\end{array}$ & $\begin{array}{c}\text { Max } \\
\text { total flow } \\
{\left[\mathrm{m}^{3} / \mathrm{s}\right]}\end{array}$ & $\begin{array}{c}\text { Hydraulic } \\
\text { gross head } \\
{[\mathrm{m}]}\end{array}$ \\
\hline SHP A & $\begin{array}{c}\text { run-of-the-river } \\
\text { (with small reservoir } \\
\text { capacity) }\end{array}$ & $\begin{array}{c}\text { Twin } \\
\text { Francis t. }\end{array}$ & 2 & 224 & 3.0 & 448 & 6.0 & 12.2 \\
\hline SHP B & $\begin{array}{l}\text { derivative with } \\
\text { reservoir } \\
\text { used in regulation }\end{array}$ & $\begin{array}{c}\text { Francis t. } \\
\text { in spiral } \\
\text { case }\end{array}$ & 2 & 1,147 & 11.0 & 2,294 & 22.0 & 13.8 \\
\hline SHP C & $\begin{array}{l}\text { conventional with } \\
\text { reservoir }\end{array}$ & $\begin{array}{c}\text { Twin } \\
\text { Francis t. }\end{array}$ & 3 & 2,400 & 7.0 & 7,200 & 21.0 & 44.8 \\
\hline \multirow{3}{*}{ SHP D } & \multirow{3}{*}{$\begin{array}{l}\text { conventional with } \\
\text { reservoir }\end{array}$} & \multirow{2}{*}{ Francis $\mathrm{t}$. } & 1 & 752 & 8.0 & \multirow{3}{*}{2,348} & \multirow{3}{*}{24.0} & \multirow{3}{*}{14.1} \\
\hline & & & 1 & 500 & 5.5 & & & \\
\hline & & $\begin{array}{c}\text { Propeller } \\
\text { shaped }\end{array}$ & 1 & 1,096 & 10.5 & & & \\
\hline SHP E & run-of-the-river & Kaplan t. & 2 & 436 & 12.0 & 872 & 24.0 & 4.5 \\
\hline \multirow[b]{2}{*}{ SHP F } & \multirow[b]{2}{*}{ run-of-the-river } & Kaplan t. & 1 & 414 & 13.0 & \multirow[b]{2}{*}{781} & \multirow[b]{2}{*}{24.0} & \multirow[b]{2}{*}{4.21} \\
\hline & & $\begin{array}{c}\text { Propeller } \\
\text { shaped }\end{array}$ & 1 & 367 & 11.0 & & & \\
\hline SHP G & $\begin{array}{c}\text { run-of-the-river } \\
\text { (with small reservoir } \\
\text { capacity) } \\
\text { (water-level control) }\end{array}$ & Kaplan t. & 1 & 232 & 7.0 & 232 & 7.0 & 4.25 \\
\hline SHP H & $\begin{array}{l}\text { run-of-the-river } \\
\text { (reserve) }\end{array}$ & Francis t. & 1 & 100 & 6.8 & 100 & 6.8 & 2.69 \\
\hline SHP I & run-of-the-river & Kaplan t. & 1 & 250 & 6.0 & 250 & 6.0 & 5.56 \\
\hline
\end{tabular}


This led to the creation of a power plant complex using various types of turbines, various hydrotechnical devices and working in different regimes. This was done to better utilize the energy of water flows in a given cross-section while simultaneously adapting to specific conditions (i.e. previously existing hydrotechnical constructions or the specifics of neighboring power plants). A summary of information on all small hydropower plants located on the Radunia River is given in Table 2.

\subsection{Characteristics of the Radunia River}

The Radunia River belongs to the group of the Przymorze rivers. Its catchment area covers $822 \mathrm{~km}^{2}$, which is $55.3 \%$ of the total area of the Motława catchment. Radunia has its source in a complex of Raduńskie lakes at an altitude of 163-165 m above sea level, length $103.2 \mathrm{~km}$ and it flows into the Motława River in the area of Żuławy Wiślane. On its entire length, it achieves an average decline of $1.64 \%$, however, the largest actual decreases in sections flowing through the so-called Jar Radunia reach as much as $4-7 \%$. In this region, the current significantly accelerates, and Radunia has the features of a upper-course river. Due to the high retention capacity of the catchment area, the annual flow irregularity factor is relatively small (below 1.5). The river is characterized by the noticeable seasonal variability of flow (Rachocki 1974). From among all the rivers of the Pomeranian Province, it is distinguished by the highest amplitude of fluctuations in flows (Ecophysiographic study... 2014).

\subsection{Analysis of operating parameters of selected SHP over a period of one year}

On the Radunia River, hydroelectric power plants of very diverse construction were built. They were installed on the same river, very close to each other. The assumption that they work in similar conditions has been made. That allows their main features and properties to be identified based on the collected data on the working time and the amount of generated power. All analyses regarding the above SHPs were made using hourly and daily data on: flows, heads, and generated power levels received from Energa Wytwarzanie SA which is the owner of these power plants.

The Radunia cascade uses turbines of various types with different operating ranges. In order to enable the analysis, it was assumed that the distribution of hourly generated power is close to the normal distribution. Values distant by more than $2 \sigma$ from the mean value have been removed This simplification allowed the values related to start-up work to be eliminated (usually the first hour after renovation), or work in very worsening hydrological conditions (an hour before switching off the turbine).

It was found that small flow power plants are characterized by the most unstable work, which is caused by their very large dependence on the instantaneous flow value. Larger two-generator 
power plants have a greater ability to react to changing conditions. Their generators can work longer in an area characterized by high efficiency (i.e. while using only one of the hydro units).

The reservoir power plants with the possibility of storing water in the period of low energy demand are many times more stable. They have the ability to generate power within the limits of the installed capacity. This is one of the basic ways of responding to variable load size and fluctuations in the amount of incoming water. SHPs with a larger number of generators stand out among the reservoir power plants, especially SHP D. It is a power plant with 3 hydrogenerators of various sizes. There is a possibility to obtain a configuration in which they operate closest to the optimal work point. During an entire year, the load of 2 turbine sets in the power plant is subject to fluctuations in the range $94-96 \%$ and $94-98 \%$ of rated power.

TABLE 3. Operating range of Radunia SHP and their generators (the values distant by $\leq 2 \sigma$ from the average value was taken into account)

TABELA 3. Zakres pracy poszczególnych EW i ich generatorów (uwzględniono wartości odległe o $\leq 2 \sigma$ od wartości średniej)

\begin{tabular}{|c|c|c|c|c|c|c|c|}
\hline \multirow[b]{2}{*}{ Name } & \multirow[b]{2}{*}{ Gen. } & \multirow[b]{2}{*}{$\begin{array}{c}\text { Nominal } \\
\text { capacity } \\
{[\mathrm{kW}]}\end{array}$} & \multicolumn{2}{|c|}{ Minimum } & \multicolumn{2}{|c|}{ Maximum } & \multirow[b]{2}{*}{$\begin{array}{c}\text { Difference } \\
\text { max-min }[\%]\end{array}$} \\
\hline & & & $\begin{array}{c}\text { capacity } \\
{[\mathrm{kW}]}\end{array}$ & $\begin{array}{c}\text { percent. of nom. } \\
\text { capacity[\%] }\end{array}$ & $\begin{array}{c}\text { capacity } \\
{[\mathrm{kW}]}\end{array}$ & $\begin{array}{c}\text { percent. of nom. } \\
\text { capacity [\%] }\end{array}$ & \\
\hline \multirow{3}{*}{ SHP A } & G1 & 224 & 119 & 53 & 202 & 90 & 37 \\
\hline & G2 & 224 & 114 & 51 & 227 & 101 & 51 \\
\hline & sum & 448 & 115 & 26 & 398 & 89 & 63 \\
\hline \multirow{3}{*}{ SHP B } & G1 & 1,147 & 616 & 54 & 998 & 87 & 33 \\
\hline & G2 & 1,147 & 820 & 71 & 1,041 & 91 & 19 \\
\hline & sum & 2,294 & 879 & 38 & 1,704 & 74 & 36 \\
\hline \multirow{4}{*}{ SHP C } & G1 & 2,400 & 1,704 & 71 & 2,064 & 86 & 15 \\
\hline & G2 & 2,400 & 1,797 & 75 & 2,252 & 94 & 19 \\
\hline & G3 & 2,400 & 1,805 & 75 & 2,381 & 99 & 24 \\
\hline & sum & 7,200 & 3,686 & 51 & 6,039 & 84 & 33 \\
\hline \multirow{4}{*}{ SHP D } & G1 & 752 & 708 & 94 & 718 & 96 & 1 \\
\hline & G2 & 500 & 341 & 68 & 506 & 101 & 33 \\
\hline & G3 & 1,096 & 1,027 & 94 & 1,072 & 98 & 4 \\
\hline & sum & 2,348 & 1,061 & 45 & 2,242 & 95 & 50 \\
\hline \multirow{3}{*}{ SHP E } & G1 & 436 & 263 & 60 & 451 & 103 & 43 \\
\hline & G2 & 436 & 201 & 46 & 296 & 68 & 22 \\
\hline & sum & 872 & 344 & 39 & 697 & 80 & 40 \\
\hline \multirow{3}{*}{ SHP F } & G1 & 414 & 281 & 68 & 393 & 95 & 27 \\
\hline & G2 & 367 & 157 & 43 & 272 & 74 & 31 \\
\hline & sum & 781 & 278 & 36 & 559 & 72 & 36 \\
\hline SHP G & G1 & 232 & 76 & 33 & 247 & 106 & 74 \\
\hline SHP H & G1 & 100 & 28 & 28 & 60 & 60 & 32 \\
\hline SHP I & G1 & 250 & 41 & 16 & 224 & 90 & 73 \\
\hline
\end{tabular}


We can divide SHPs into two groups by analyzing the working time of individual power plants The first include the run-of-the-river SHPs. From the point of view of the power system, they are primary power plants. This is due to the fact that most of them work almost constantly. In the period in which inflows become too small for supplying all of the hydroelectric assemblies of a given power plant, it is possible to regulate this by putting one or more generators away. They can be switched alternately to avoid the excessive wear of one of the turbine sets and enable ongoing maintenance and inspection. The time of continuous operation of a single turbine set in SHP A in 2016 usually ranged from $96 \mathrm{~h}$ to $144 \mathrm{~h}$. SHP A has the ability to work throughout the year (standstill $<0.3 \%$ of the year), when SHP G and $\mathrm{H}$ were stopped at the time of inspection (the stoppage lasted 4 and $7 \%$ a year).

The other group are reservoir power plants. Radunia's power plants have small reservoirs. They usually work twice a day - during the morning and evening peak hours. Therefore, they operate only for about $38 \%$ of the year, and most of the stops are caused by the need for repairs. Adaptation of reservoir hydropower plants to hydrological conditions or variable loads is possible, among others by using only part of the turbine sets. In the analyzed power plants, they worked through $19-36 \%$ of the year. In analogy to the run-of-the-river SHPs, they were usually switched alternately to reduce the wear of the elements. During heavy loads and a high level of water in the river, the power plants worked using all the turbines. Several times during extraordinarily high rainfalls, 24-hour work was necessary. This aimed at lowering the water level in the power plant's reservoirs and adapting them to receive flood water.

\subsection{Flow characteristics}

\subsubsection{Run-of-the-river hydroelectric power stations}

Figure 1 shows SHP A data. It is a run-of-the-river power plant located at the highest of all SHPs in Radunia. Therefore, the amount of water flowing into it depends only on the amount of atmospheric precipitation and climatic conditions in the area of the corresponding catchment. The size of the inflow and flow through power plant are very similar and during the year are subject to constant, fast fluctuations of high amplitude. Accordingly, the level of power generated in the power plant may be significantly increased (even several-fold) in just a few hours. Table 2 and curves describing precipitation, flow and head (Figure 1) allow to conclude that it is difficult to control power generation in this type of power plant and depends mainly on the amount of precipitation in it's the catchment area. Therefore, it is possible to plan the work of such a plant in advance of no more than a few days. 


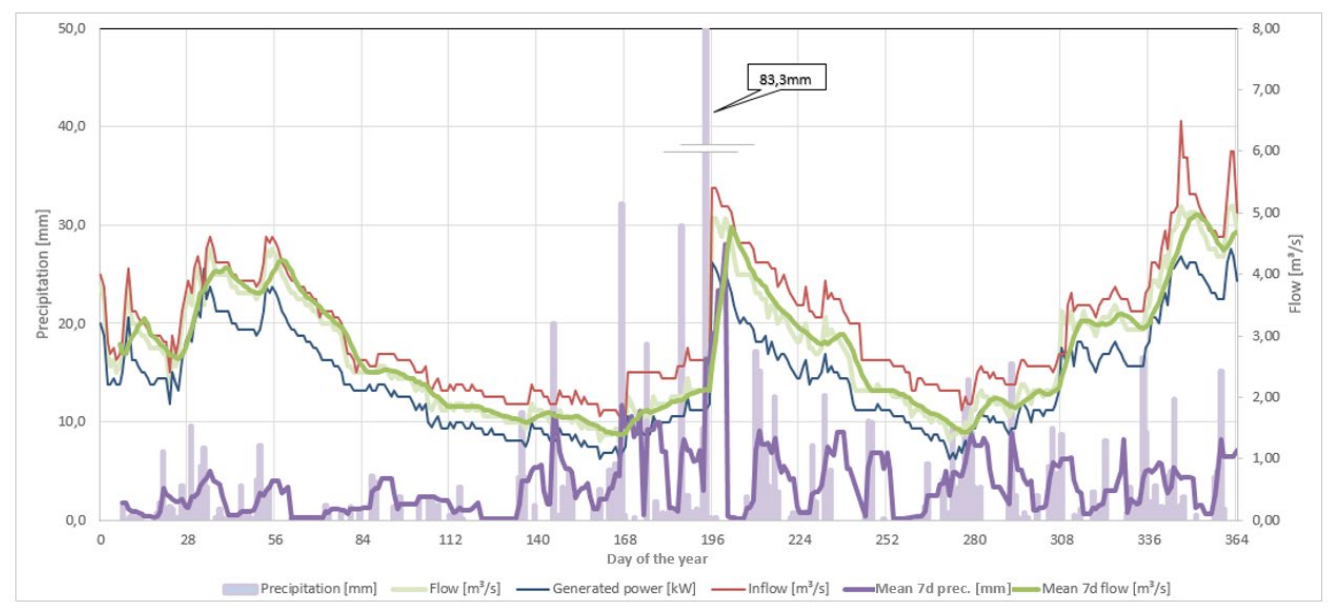

Fig. 1. Size of the 24-hour atmospheric precipitation, inflows, flows and the power generated by SHP A ("7d'values are 7-day averages)

Source: own study

Rys. 1. Wielkość dobowego opadu atmosferycznego, dopływów, przepływów oraz mocy generowanej przez MEW A (Wartości „7d” to średnie 7 dniowe)

\subsubsection{Conventional hydroelectric power stations}

Figure 2 presents information on the variability of inflows and flows by the reservoir power plant, which is SHP B. Due to the fact that it lies directly below the previously described run-of -the-river SHP A, the curve describing the water supply has a shape very similar to the inflow curve to the higher power plant. The operation of the reservoir created by the dam is also clearly visible. Thanks to it, the flow can be controlled to a much greater extent. This allows for the more efficient energy use of water resources, because generators can work in conditions closer to optimal ones. In addition, the use of the power plant's reservoir for flood protection of the areas below is also visible.

Depending on the size of the reservoir, short-term regulation is possible (during peak hours), regulation in a weekly or seasonal cycle. In the latter case, municipal needs are usually prioritized to which the energy use of water resources is adjusted. The water supply in the reservoir is then divided into a retention layer (reserve before the period of increased inflows or maintaining a level adequate to meet the municipal needs in the dry season) and the energy layer. A flood reserve for the arrival of large water is always left in the reservoir. 


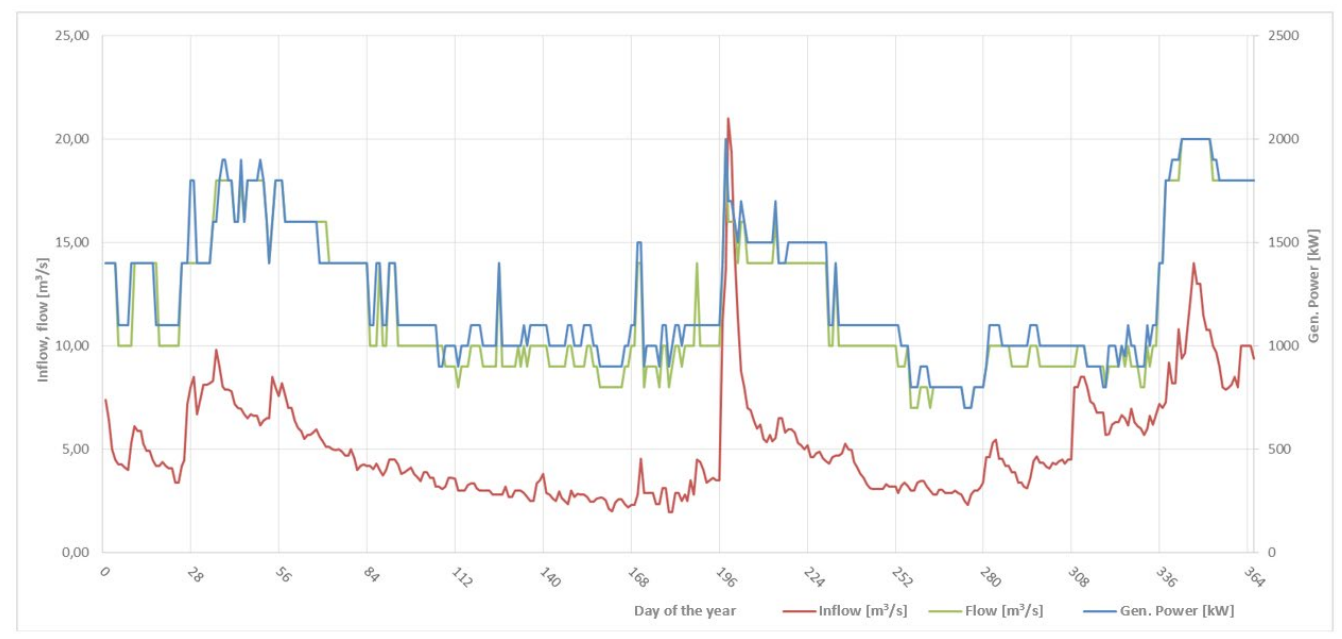

Fig. 2. Size of inflows, flows and power generated by SHP B

Rys. 2. Wielkość dopływów, przepływów oraz mocy generowanej przez MEW B

\section{Possible degree of weekly regulation}

\subsection{Model of a hydroelectric power plant}

Based on previous observations, a mathematical model for a small hydroelectric power plant (on which simulations have been carried out) has been developed. The previous analysis allowed to conclude that the hydropower plants with retention reservoirs have much greater possibilities of power generation control. They are characterized by the ability to respond to meteorological and hydrological conditions in the catchment area, through flood protection during large river floods, or saving the water necessary for irrigation during drought. Their operation can also be controlled in connection, for example, with the anticipated increase in demand over the next days.

While selecting parameters of the test power plant and hydrological conditions, a previously performed analysis of the operation of hydropower plants with reservoirs was used, including mainly SHP B and SHP D characteristics. Tables 4 and 5 contain selected parameters of existing and test SHPs. 
TABLE 4. Quantities characterizing the reservoirs of individual power plants

TABELA 4. Wielkości charakteryzujące zbiorniki poszczególnych elektrowni

\begin{tabular}{|c|c|c|c|}
\hline \multirow{2}{*}{ Name } & \multicolumn{3}{|c|}{ Reservoir capacity $\left[\mathrm{mln}^{3}\right]$} \\
\cline { 2 - 4 } & usable & total & emergency \\
\hline SHP B & 0.530 & 1.550 & 0.110 \\
\hline SHP C & 1.236 & 2.453 & 0.180 \\
\hline SHP D & 1.800 & 3.400 & 0.600 \\
\hline SHP G & 0.221 & 0.332 & 0.160 \\
\hline Test SHP & 1.000 & 2.000 & 0.500 \\
\hline
\end{tabular}

Source: own study.

TABLE 5. Minimum and maximum flows of individual power plants

TABELA 5. Przepływy minimalne i maksymalne poszczególnych elektrowni

\begin{tabular}{|c|c|c|c|c|c|}
\hline \multirow{2}{*}{ Name } & \multirow{2}{*}{ Hydro generator } & \multicolumn{4}{|c|}{ Flows through the turbine } \\
\hline & & \multicolumn{2}{|c|}{$\operatorname{minimal}\left[\mathrm{m}^{3} / \mathrm{s}\right]$} & \multicolumn{2}{|c|}{$\operatorname{maximal}\left[\mathrm{m}^{3} / \mathrm{s}\right]$} \\
\hline \multirow{2}{*}{ SHP B } & $\mathrm{HZ1}$ & 3.30 & \multirow{2}{*}{3.30} & 11.00 & \multirow{2}{*}{22.00} \\
\hline & $\mathrm{HZ2}$ & $3.30\left[8.0^{*}\right]$ & & 11.00 & \\
\hline \multirow{3}{*}{ SHP C } & $\mathrm{HZ} 1$ & 2.16 & \multirow{3}{*}{2.16} & 7.00 & \multirow{3}{*}{21.00} \\
\hline & $\mathrm{HZ2}$ & 2.16 & & 7.00 & \\
\hline & $\mathrm{HZ3}$ & 2.40 & & 7.00 & \\
\hline \multirow{3}{*}{ SHP D } & $\mathrm{HZ1}$ & 2.34 & \multirow{3}{*}{1.58} & 8.00 & \multirow{3}{*}{24.00} \\
\hline & $\mathrm{HZ2}$ & 1.58 & & 5.50 & \\
\hline & $\mathrm{HZ3}$ & $2.96\left[8.0^{*}\right]$ & & 10.50 & \\
\hline \multirow{2}{*}{ SHP E } & $\mathrm{HZ1}$ & 4.05 & \multirow{2}{*}{4.05} & 12.00 & \multirow{2}{*}{24.00} \\
\hline & $\mathrm{HZ2}$ & 4.05 & & 12.00 & \\
\hline \multirow{2}{*}{ SHP F } & $\mathrm{HZ1}$ & 4.05 & \multirow{2}{*}{3.15} & 13.00 & \multirow{2}{*}{24.00} \\
\hline & $\mathrm{HZ2}$ & 3.15 & & 11.00 & \\
\hline \multirow{3}{*}{ Test SHP } & $\mathrm{HZ1}$ & 2.00 & \multirow{3}{*}{2.00} & 6.00 & \multirow{3}{*}{24.00} \\
\hline & HZ2 & 3.00 & & 8,00 & \\
\hline & $\mathrm{HZ3}$ & 4.00 & & 10,00 & \\
\hline
\end{tabular}

* Recommended minimum flow due to possible vibrations.

Source: own study.

76 


\subsection{Identification of possible degree of regulation in the hydro power supply}

\subsubsection{A single hydroelectric plant}

Due to the inability to adequately represent the function of three variables in subsequent iterations (including 24-hour cycles of work), the simulation results were shown on the example of several selected scenarios. The amount of water remaining in the reservoir after the first 24-hour cycle, depending on the set flow and working time of the water components, is illustrated in Figure 3. It shows the wide range of regulation possibilities of the hydroelectric power plant with a reservoir.

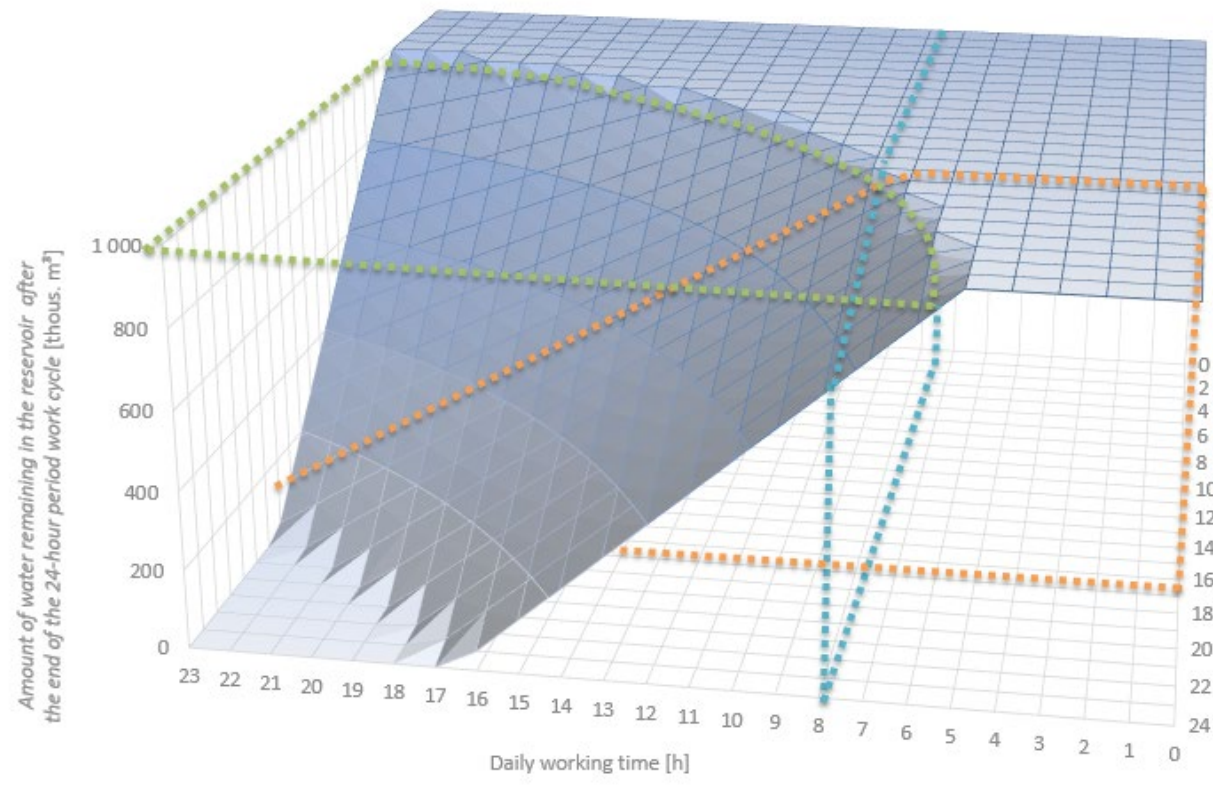

Fig. 3. The amount of water remaining in the reservoir of the test hydroelectric plant after the end of the first 24-hour period work cycle. The planes corresponding to the values $Q_{P j}=16\left[\mathrm{~m}^{3} / \mathrm{s}\right]$ and $t_{k}=8[\mathrm{~h}]$ (scenario I on the next page) were marked. The location of the intersection of the above planes shows how much water will remain in the power plant's reservoir at given operating parameters

Source: own study

Rys. 3. Ilość wody pozostałej w zbiorniku testowej elektrowni wodnej po zakończeniu pierwszego 24-godz. cyklu pracy. Oznaczone zostały płaszczyzny odpowiadające wartościom $Q_{P j}=16\left[\mathrm{~m}^{3} / \mathrm{s}\right]$ i $t_{k}=8[\mathrm{~h}]$ (scenariusz I na kolejnej stronie). Położenie punktu przecięcia ww. płaszczyzn pokazuje, ile pozostanie wody w zbiorniku elektrowni przy danych parametrach pracy

Each of the scenarios aimed at showing the control possibilities of a hydroelectric power plant in the field of power level regulation generated in connection with, for example, the expec- 
ted increase of demand over the next few days. In all scenarios it was assumed that the reservoir is completely full at the beginning of the simulation.

In basic scenarios, one week was assumed as a time of the analysis. The maximum available flow through the power plant, at which the loss of water used during working days can be refilled during the weekend, when the load is lower. It was assumed that on Saturday and Sunday it is $85 \%$ and $70 \%$ of the work day's load. The flow through hydro-units can be reduced in a proportional way.

Scenarios with increased generation allowed to check what conditions must be met so that SHP could increase the amount of energy generated by 25,50 or $100 \%$ for one 24 -hour cycle or allow the transition to continuous operation for a short period of time. Over the next days, the level of generated power should be limited to the level in which the reservoir can be fully refilled before the end of the week.

TABLE 6. Summary of operating parameters of the test power plant for initial scenarios

TABELA 6. Zestawienie parametrów pracy testowej EW dla scenariuszy początkowych

\begin{tabular}{|c|c|c|c|c|}
\hline Scenario & $\begin{array}{c}\text { Inflow } \\
\mathrm{QD} \\
{\left[\mathrm{m}^{3} / \mathrm{s}\right]}\end{array}$ & $\begin{array}{c}\text { Flow } \\
Q_{P j}\left[\mathrm{~m}^{3} / \mathrm{s}\right]\end{array}$ & $\begin{array}{c}\text { Instantaneous power } \\
\text { (percent. of nom. capacity) } \\
{[\%]}\end{array}$ & $\begin{array}{c}\text { Operating time } t_{k} \\
{[\mathrm{~h}]}\end{array}$ \\
\hline 1 & 5.0 & 16.0 & 67 & 8.0 \\
\hline 2 & 5.0 & 9.1 & 38 & 14.0 \\
\hline 3 & 5.0 & 5.3 & 22 & 24.0 \\
\hline
\end{tabular}

Source: own study.

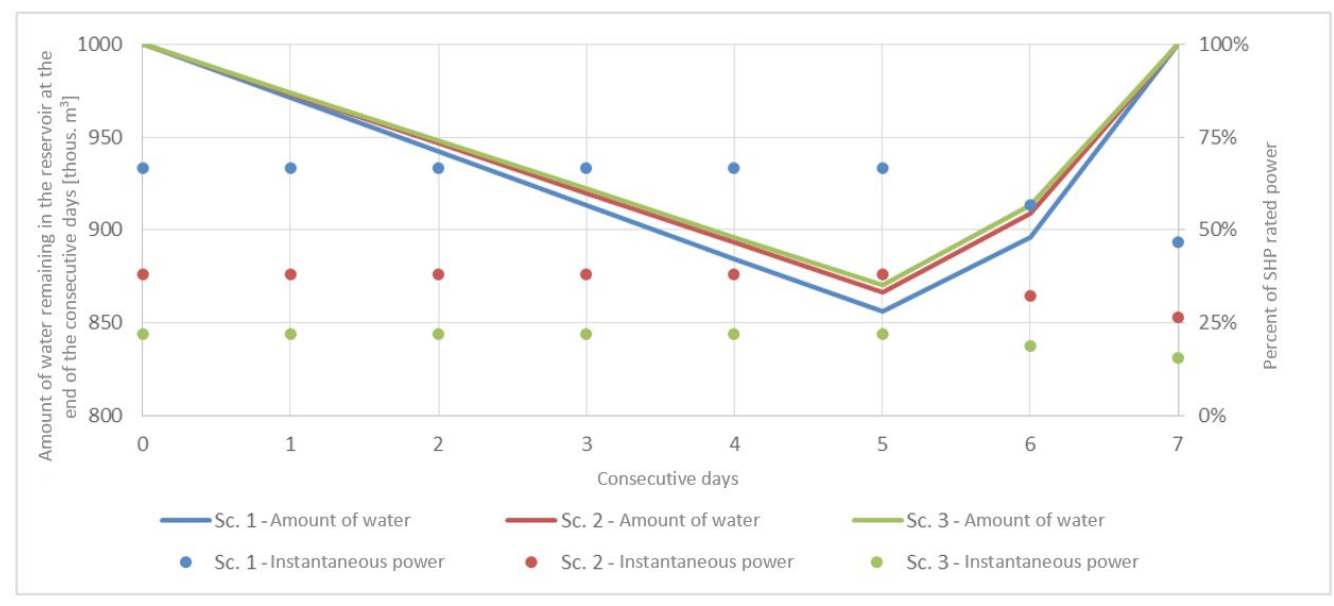

Fig. 4. The amount of water remaining in the reservoir at the end of the consecutive days and the instantaneous power of power plant for the initial scenarios

Source: own study

Rys. 4. Ilość wody pozostałej w zbiorniku na koniec kolejnych dób oraz moc chwilowa EW dla scenariuszy początkowych 
In the scenarios described above, the test hydropower plant is evenly loaded over all working days. There is a reduction in the energy demand in the energy system at the weekend, which allows the level of generated power to be lowered and, at the same time, flow through the power plant. It was assumed that the decrease in demand is respectively $15 \%$ on Saturday and $30 \%$ on Sunday from the normal day (based on average loads in the National Power System). This means that scenarios 1-3 describe situations in which a test power plant operates in accordance with the adopted work schedule and it is not necessary to perform extraordinary operations (for example to balance the power system).

The attached curves (Figure 4) allow to conclude that the differences between the individual scenarios are small. This is due to the fact that the average daily flow each day is very close to the value of water supply $\mathrm{Q}_{\mathrm{D}}$ to the reservoir, because the water loss caused by work within five working days must be completed within two days of the weekend. With the operating conditions assumed in scenarios $1-3$, the lowest calculated amount of water in the reservoir is $856,000 \mathrm{~m}^{3}$. This means that less than $15 \%$ of the energy potential of the reservoir is used, which could be considered as a failure to comply with the requirements of the Water Law for the conditions of issuing a water permit. This was one of the reasons for conducting further simulations to show the possibility of using the hydro-energy potential in a technically and economically justified way.

In the subsequent scenarios (i.e. sc. $4 \mathrm{a}-7 \mathrm{~b}$ ), the test hydropower plant works in a way that will exploit the majority of the energy potential of the reservoir. They describe situations in which it may be necessary to increase the level of generated power by power plants or to extend the time in which it works (Table 7, Figure 5). This may be caused by, among others, the need to temporarily shut down an adjacent power plant or unexpectedly increased energy demand.

A short-term (for a period of one day) increase in the level of generated power, and the flow at the same time, allowed to use up to $95 \%$ of the water initially collected in the reservoir. It can therefore be concluded that the construction of the reservoir of this size was economically justified. Scenarios $4 \mathrm{a}, 4 \mathrm{~b}$ and $5 \mathrm{a}$ are modifications of cases in which the power plant worked during peak load hours or throughout the day. They show that it is possible to increase the level of generated power during one day by $25-50 \%$ (relative to the reference value - flow corresponding to scenarios 1-3), without the need to significantly reduce the flow on consecutive days (decrease $<10 \%$ ). The next analyzed cases $-5 \mathrm{~b}$ and $6 \mathrm{a}$ - show that a two-fold increase in the flow, in relation to the reference value, allows us to use almost half of the potential of the test hydropower plant reservoir. It is necessary to limit the level of power generated by almost $20 \%$ in the following days. This reveals the possibility of a power generation system response to an increased peak load. The following power reduction is relatively small, so it should be possible to compensate it with other sources.

In one of the scenarios (sc. 6b) there was a threefold increase in the flow within only one day. This resulted in an almost complete emptying of the reservoir, as well as the need to drastically reduce generation - by $36 \%$ in relation to the reference value and almost by $80 \%$ in relation to the maximum power level generated in this scenario in the following days. This shows the possibility of a radical increase in the level of generated power for 24 hours in the case of DSO (Distribution System Operator) demanding. 
TABLE 7. Summary of operating parameters of the test power plant for scenarios with increased power generation

TABELA 7. Zestawienie parametrów pracy testowej elektrowni dla scenariuszy ze zwiększoną generacją

\begin{tabular}{|c|c|c|c|c|c|c|c|c|c|}
\hline \multirow{4}{*}{ 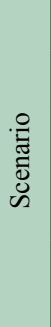 } & \multirow{3}{*}{ 孞 } & \multicolumn{4}{|c|}{ Increased generation } & \multicolumn{4}{|c|}{ Reservoir refilling } \\
\hline & & \multicolumn{2}{|r|}{ flow } & \multirow{2}{*}{$\begin{array}{c}\text { instantaneous } \\
\text { power } \\
\text { (percent. of } \\
\text { nom. capacity) }\end{array}$} & \multirow[b]{2}{*}{$\begin{array}{l}\text { op. } \\
\text { time }\end{array}$} & \multicolumn{2}{|r|}{ flow } & \multirow{2}{*}{$\begin{array}{l}\text { instantaneous } \\
\text { power } \\
\text { (percent. of } \\
\text { nom. capacity) }\end{array}$} & \multirow[b]{2}{*}{$\begin{array}{c}\text { op. } \\
\text { time }\end{array}$} \\
\hline & & $\begin{array}{c}\text { abs. } \\
\text { value }\end{array}$ & $\begin{array}{l}\text { relative to } \\
\text { the baseline } \\
\text { scenario }\end{array}$ & & & $\begin{array}{c}\text { abs. } \\
\text { value }\end{array}$ & $\begin{array}{l}\text { relative to } \\
\text { the baseline } \\
\text { scenario }\end{array}$ & & \\
\hline & $\begin{array}{c}\text { QD } \\
{\left[\mathrm{m}^{3} / \mathrm{s}\right]}\end{array}$ & $\begin{array}{c}Q_{P j} \\
{\left[\mathrm{~m}^{3} / \mathrm{s}\right]}\end{array}$ & {$[\%]$} & {$[\%]$} & $t_{k}[\mathrm{~h}]$ & $\begin{array}{c}Q_{P j} \\
{\left[\mathrm{~m}^{3} / \mathrm{s}\right]}\end{array}$ & {$[\%]$} & {$[\%]$} & $t_{k}[\mathrm{~h}]$ \\
\hline $4 \mathrm{a}$ & 5.0 & 20.0 & 125 & 83 & 8.0 & 15.3 & 96 & 64 & 8.0 \\
\hline $4 b$ & 5.0 & 24.0 & 150 & 100 & 8.0 & 14.5 & 91 & 60 & 8.0 \\
\hline $5 \mathrm{a}$ & 5.0 & 13.7 & 150 & 57 & 14.0 & 8.3 & 91 & 35 & 14.0 \\
\hline $5 b$ & 5.0 & 18.2 & 200 & 76 & 14.0 & 7.5 & 82 & 31 & 14.0 \\
\hline $6 a$ & 5.0 & 10.6 & 200 & 44 & 24.0 & 4.3 & 81 & 18 & 24.0 \\
\hline $6 b$ & 5.0 & 15.9 & 300 & 66 & 24.0 & 3.4 & 64 & 14 & 24.0 \\
\hline $7 \mathrm{a}$ & 5.0 & 16.0 & - & 67 & 24.0 & 16.0 & - & 67 & 5.1 \\
\hline $7 b$ & 5.0 & 9.1 & - & 38 & 48.0 & 9.1 & - & 38 & 9.7 \\
\hline
\end{tabular}

Source: own study.

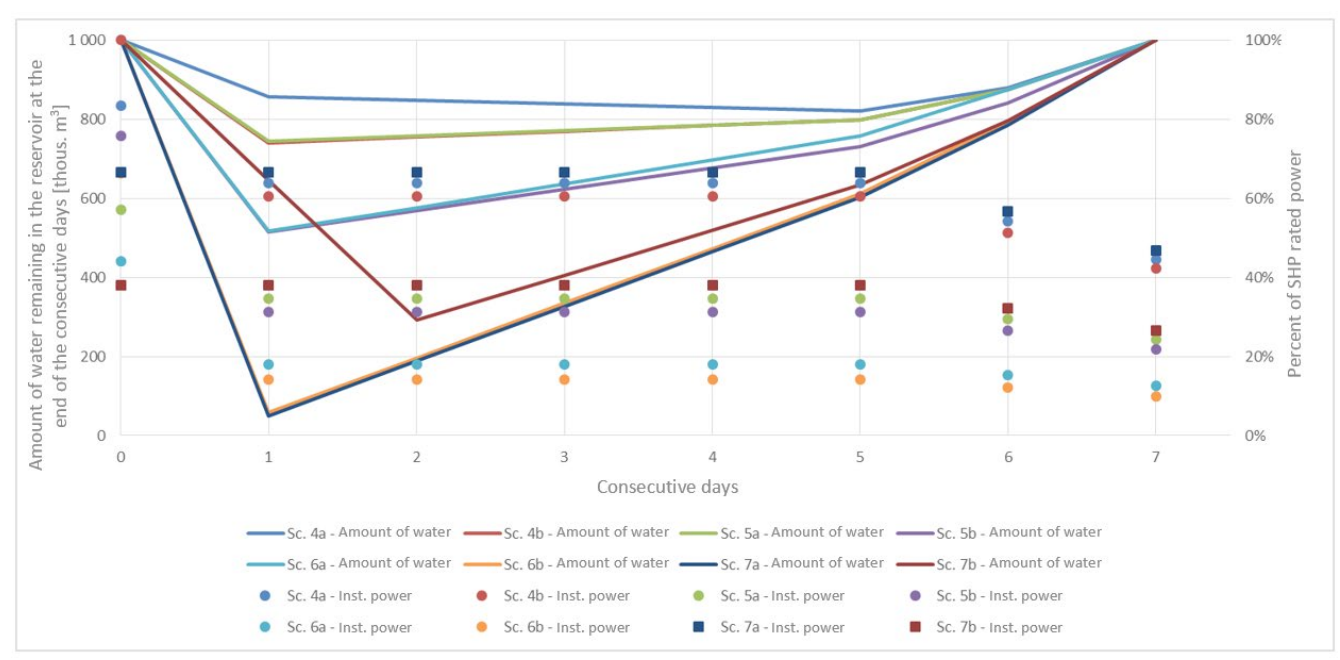

Fig. 5. The amount of water remaining in the reservoir at the end of the consecutive days and the instantaneous power of power plant for scenarios with increased power generation

$$
\text { Source: own study }
$$

Rys. 5. Ilość wody pozostałej w zbiorniku na koniec kolejnych dób oraz moc chwilowa EW dla scenariuszy ze zwiększoną generacją 
The last two scenarios describe cases in which the working time of a power plant is extended while maintaining the same level of generated power. Situations like this may occur when it is necessary to stop the neighboring power plant, for example due to a minor failure or maintenance of its equipment.

In scenario $7 \mathrm{a}$, the reservoir was almost completely emptied as a result of extending the working time in the first day (from 16 to 24 hours). This forced a significant reduction of its operation time in the following days (up to about 5 hours). Comparing these results with the information from the baseline scenario (diagram 1), we can conclude that the test power plant is able to operate with a given flow $\left(Q_{P j}=16\left[\mathrm{~m}^{3} / \mathrm{s}\right]\right)$ during peak hours or one day in a 24-hour regime. In next couple of days, it can work only for 5 hours (i.e. during the morning or evening peak hours).

The last of the discussed scenarios (sc. 7b) shows what conditions must be met to allow continuous power plant operation for 48 hours. This is a modification of scenario 2 , so it is an analysis based on the change of working time with the constant level of generated power (and thus constant flow $-Q_{P j}=9.1\left[\mathrm{~m}^{3} / \mathrm{s}\right]$ ). The comparison of the baseline scenario (sc. 2) and the modified scenario (sc. 7b) allows to conclude that the test power plant can work with the abovementioned power level on a daily basis with a fixed number of hours of work per day or two days in a 24-hour system, and in next couple of days for almost 10 hours (i.e. during morning and evening peak hours).

\subsubsection{Cascade of hydroelectric power plants}

In order to determine the ability to regulate the work of SHP working in the cascade, a previously created test model of a hydropower plant was used. The cascade consisted of a system of two hydroelectric power plants, where the upper power plant was a power plant modeled earlier. Since there would be no significant differences from the previous simulations (apart from the proportional increase in the amount of generated energy) in the case of the use of a run-of-the-river power plant, this type of power plant was rejected. Certain independence from the operation of the upper power plant gave the use of a second reservoir power plant. Therefore, a cascade consisting of two reservoir power plants with the same parameters for reservoirs and hydro generators was modeled, which made it possible to compare the simulation results carried out on both models.

Scenarios $8 \mathrm{a}-9 \mathrm{c}$ provide an analysis of the possibilities of cooperation and power generation control by a cascade of two identical reservoir hydroelectric power plants (Table 8, Table 9, Figure 6, Figure 7). It was assumed that the upper power plant will work according to selected scenarios from previous analyses. The lower power plant will operate with smaller flows, equal to or larger than the flow of the upper power plant.

In cases 8a and 9a, the cascade's behavior was examined with equal flows through both power plants and at the same time of their work. In this case, the bottom power plant completely does not use its own reservoir, because the inflow and flow volumes are equal. This means that it 
TABLE 8. Summary of operating parameters of lower power plant for the initial scenarios

TABELA 8. Zestawienie parametrów pracy dolnej EW dla scenariuszy początkowych

\begin{tabular}{|c|c|c|c|c|c|}
\hline \multirow{2}{*}{ 恋 } & \multirow{2}{*}{ 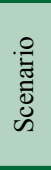 } & Inflow & Flow & \multirow{2}{*}{$\begin{array}{c}\text { Instantaneous power } \\
\text { (percent. of nom. capacity) } \\
{[\%]}\end{array}$} & \multirow{2}{*}{$\begin{array}{c}\begin{array}{c}\text { Operating } \\
\text { time }\end{array} \\
\mathrm{h} \\
{\left[t_{k}\right]}\end{array}$} \\
\hline & & $\mathrm{QD}\left[\mathrm{m}^{3} / \mathrm{s}\right]$ & $Q_{P j}\left[\mathrm{~m}^{3} / \mathrm{s}\right]$ & & \\
\hline 1 & 1 & 5.0 & 16.0 & 67 & 8.0 \\
\hline 2 & $8 \mathrm{a}$ & $\mathrm{QP}_{1}$ & 16.0 & 67 & 8.0 \\
\hline 2 & $8 \mathrm{~b}$ & $\mathrm{QP}_{1}$ & 5.0 & 21 & 24.0 \\
\hline 2 & $8 \mathrm{c}$ & $\mathrm{QP}_{1}$ & 17.0 & 71 & 8.0 \\
\hline
\end{tabular}

Where: $\mathrm{QP}_{1}-$ inflow equal to inflow in scenario 1.

TABLE 9. Summary of operating parameters of the lower power plant for scenarios with increased power generation

TABELA 9. Zestawienie parametrów pracy dolnej EW dla scenariuszy ze zwiększoną generacją

\begin{tabular}{|c|c|c|c|c|c|c|c|c|}
\hline \multirow{3}{*}{$\stackrel{\Xi}{\tilde{\omega}}$} & \multirow{3}{*}{ 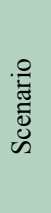 } & & \multicolumn{3}{|c|}{ Increased generation } & \multicolumn{3}{|c|}{ Reservoir refilling } \\
\hline & & \multirow{2}{*}{$\begin{array}{c}\text { inflow } \\
\text { QD } \\
{\left[\mathrm{m}^{3} / \mathrm{s}\right]}\end{array}$} & \multirow{2}{*}{ 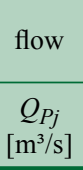 } & \multirow{2}{*}{$\begin{array}{l}\text { instantaneous power } \\
\text { (percent. of nom. } \\
\text { capacity) [\%] }\end{array}$} & \multirow{2}{*}{$\begin{array}{c}\begin{array}{c}\text { operating } \\
\text { time }\end{array} \\
\mathrm{h} \\
{\left[t_{k}\right]}\end{array}$} & \multirow{2}{*}{$\frac{\text { flow }}{Q_{P j}}$} & \multirow{2}{*}{$\begin{array}{l}\text { instantaneous power } \\
\text { (percent. of nom. } \\
\text { capacity) }[\%]\end{array}$} & \multirow{2}{*}{$\begin{array}{c}\begin{array}{c}\text { operating } \\
\text { time }\end{array} \\
\mathrm{h} \\
{\left[t_{k}\right]}\end{array}$} \\
\hline & & & & & & & & \\
\hline 1 & $6 a$ & 5.0 & 10.6 & 44 & 24.0 & 4.3 & 18 & 24.0 \\
\hline 2 & $9 \mathrm{a}$ & QP6a & 10.6 & 44 & 24.0 & 4.3 & 18 & 24.0 \\
\hline 2 & $9 \mathrm{~b}$ & QP6a & 5.0 & 21 & 24.0 & 5.0 & 21 & 24.0 \\
\hline 2 & $9 \mathrm{c}$ & QP6a & 10.6 & 44 & 48.0 & 3.0 & 13 & 24.0 \\
\hline
\end{tabular}

Source: own study.

Where: QP6a - inflow equal to inflow in scenario 6a.

works as a run-of-the-river power plant. In comparison to the baseline scenario, which described a single power plant, the level of the total power generated by the cascade increased twofold.

In scenarios 8b-9b, the lower power plant uses its reservoir (equalizing reservoir) to regulate the flow of water below an intermittently operated hydropower station. It converts a large peak outflow into a daily average outflow. This means that the amount of water flowing through is close to the value of the current inflow to the upper power plant, and the level of power generated is constant throughout the entire week. In these cases, it was assumed that at the beginning of the analysis the power plant's reservoir is not completely full. And thanks to the fact that it has the ability to store more water during periods of high water flows (during the peak load of the power system).

The last cases describe situations in which a lower power plant works with larger flows than the upper power plant. In scenario $8 \mathrm{c}$, the lower power plant works for 5 days with the flow 


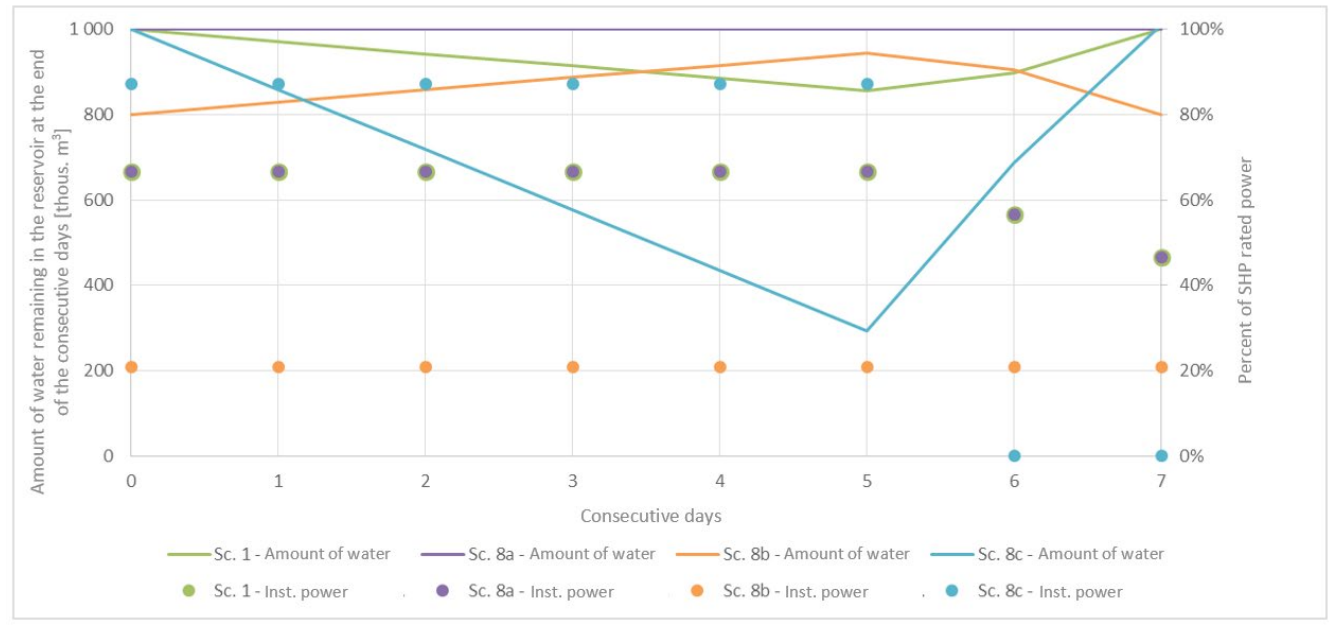

Fig. 6. The amount of water remaining in the reservoir at the end of the consecutive days and the instantaneous power of lower power plant for the initial scenarios Source: own study

Rys. 6. Ilość wody pozostałej w zbiorniku na koniec kolejnych dób oraz moc chwilowa dolnej EW dla scenariuszy początkowych

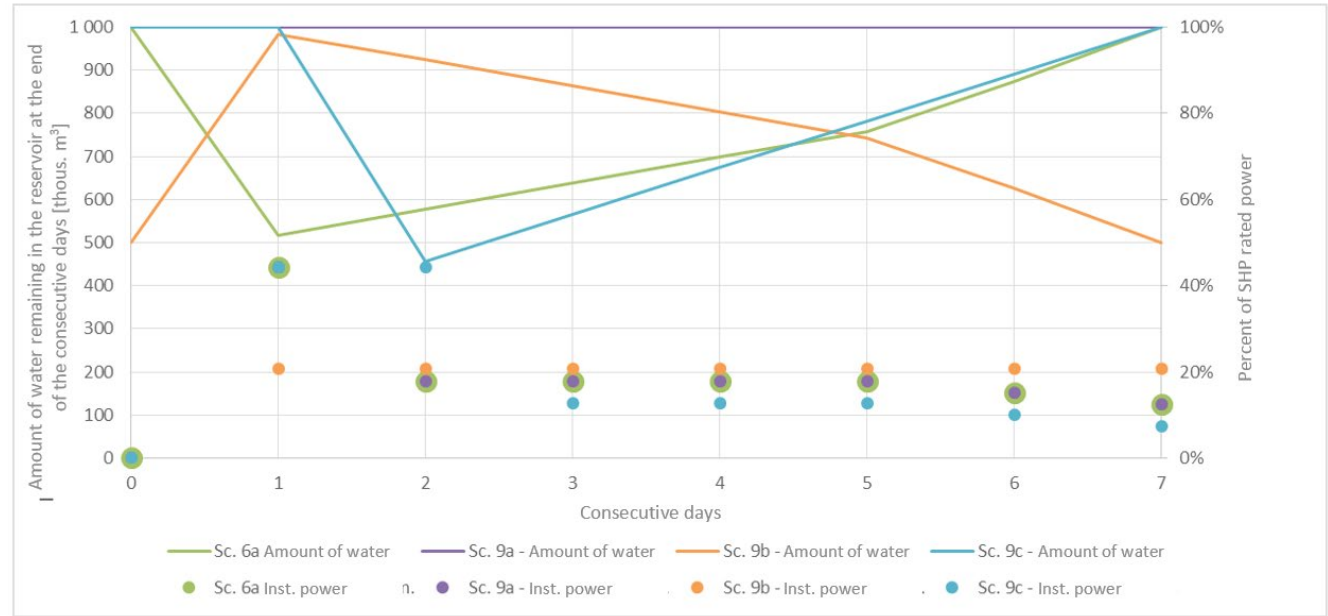

Fig. 7. The amount of water remaining in the reservoir at the end of the consecutive days and the instantaneous power of lower power plant for scenarios with increased power generation

$$
\text { Source: own study }
$$

Rys. 7. Ilość wody pozostałej w zbiorniku na koniec kolejnych dób oraz moc chwilowa dolnej EW dla scenariuszy ze zwiększoną generacją 
greater than the flow of the upper power plant, and it is stopped during the weekend. Such an operation scheme can be implemented, for example, in the case of the need to increase the level of power generated due to increased demand in the factory that only operates during the work week. A similar situation took place in cases $4 \mathrm{a}$ and $4 \mathrm{~b}$, but the SHPs cascade has the ability to increase the output power level in a 5 times longer timeframe.

The last analyzed case (sc. 9c) is a development of scenario 6a. On the first day, the lower power plant works with the same flow as the upper power plant, which allows it to maintain a constant high-water level in the lower reservoir. Thanks to this, the next day, the lower power plant can maintain a high flow for the next 24 hours. The cascade can increase generation to $400 \%$ in relation to base scenario 3 during the first day, up to $180 \%$ during the second day and by $36 \%$ during the following days.

\section{Conclusions}

The analysis of the technical, legal, hydrological conditions and operation of the existing group of power plants showed that the largest possibilities of power generation control in small hydro installations may be ensured by having a reservoir and a couple of hydroelectric units of different rated power. Simulations were carried out using the developed mathematical model of such power plants.

The research aimed at determining the possibilities of power generation control in a few-day horizon by both a single SHP and a cascade of two identical power plants of this type. It was found that, depending on the operation scheme, it is possible to use SHP during the base and peakload of the power system. In addition, even a single power plant has a relatively large capacity to respond to changes in the power system power balance. These abilities significantly increase in the case of building another SHP on a given watercourse. The cascade of reservoir hydropower plants has a much greater ability to store energy and give it back in time. What is more, the existence of a second power plant equipped with a reservoir allows for the significant reduction of the amplitude of flows in the river below the cascade, which will reduce the negative impact of the cascade on the environment.

The completion of this these analyses was possible with the support of Energa Wytwarzanie SA - owner and operator of the hydro power stations on the Radunia River. 


\section{References}

Hoffmann, M. 1992. Small hydropower plants - guide (Mate elektrownie wodne - poradnik). Warszawa: Nabba Sp. z o. o. (in Polish).

KorCZAK, A. 2011. Hydropower in Poland. Current state and development prospects (Energetyka wodna w Polsce. Stan aktualny i perspektywy rozwoju). Gliwice: Politechnika Śląska (in Polish).

Field study... 2005. Field study on the potential use of small river resources for energy generation in Poland (Studium terenowe możliwości wykorzystania energetycznego zasobów małych cieków wodnych $w$ Polsce). Opracowanie Energoprojekt Warszawa SA; Warszawa (in Polish).

Small... 2004. Small hydropower situation in the new EU member states and candidate countries. TNSHP ESHA; Brussels.

WFD - Directive 2000/60/EC of the European Parliament and of the Council of 23 October 2000 establishing a framework for Community action in the field of water policy (Directive 2000/60/EC - Dyrektywa Parlamentu Europejskiego i Rady z dnia 23 października 2000 r. ustanawiająca ramy wspólnotowego działania $w$ dziedzinie polityki wodnej) (in Polish).

Water Law - The Act dated 18 July 2001 - Water Law. Journal of Laws. 2017 item 1121 (Ustawa z dnia 18 lipca 2001 r. - Prawo wodne. Dz.U. 2017 poz. 1121) (in Polish).

Environmental Protection Law - The Act dated 27 April 2001 - Environmental protection law. Journal of Laws. 2001 No. 62 item 627 (Ustawa z dnia 27 kwietnia 2001 r. - Prawo ochrony środowiska. Dz.U. $2001 \mathrm{nr} 62$ poz. 627).

Water... 2005. Water management strategy (Strategia gospodarki wodnej). Ministerstwo Środowiska, przyjęta przez RM w dniu 13 września 2005 r. (in Polish).

Proposal... 2010. Proposal of the State Water Policy until 2030 (Projekt polityki wodnej Państwa do roku 2030). KZGW; Warszawa (in Polish).

Restor... 2017. [Online] http://www.restor-hydro.eu/ [Dostęp: 2017-04-14].

MATUSZEK, W. 2005. Current status and development of hydropower as a source of renewable energy (Stan aktualny i rozwój hydroenergetyki jako źródło OZE). Elektroenergetyka no 1(52) (in Polish).

Ecophysiographic study... 2014 - Ecophysiographic study for the Spatial Development Plan of the Pomeranian voivodeship (Opracowanie Ekofizjograficzne do Planu Zagospodarowania Przestrzennego Województwa Pomorskiego). Pomorskie Biuro Planowania Regionalnego; Gdańsk - Słupsk (in Polish).

RACHOCKI, A. 1974. The progress and intensity of modern river processes in the Radunia riverbed (Przebieg i natężenie wspótczesnych procesów rzecznych w korycie Raduni). Warszawa: IG PAN (in Polish). 


\title{
Identyfikacja możliwości kształtowania mocy generowanej w małych elektrowniach wodnych w horyzoncie kilkudniowym
}

\author{
Streszczenie
}

W artykule omówiono znaczenie elektrowni wodnych w systemie elektroenergetycznym Polski oraz określono uwarunkowania prawne dotyczące funkcjonowania małych elektrowni wodnych w systemie elektroenergetycznym. Przeanalizowano zjawiska zachodzące w układzie hydrologicznym małych elektrowni wodnych oraz ich wpływ na środowisko naturalne.

Na podstawie analizy funkcjonowania grupy małych elektrowni wodnych działających na rzece Raduni, charakteryzujących się różnymi rozwiązaniami technicznymi, dokonano identyfikacji zależności między różnymi rodzajami elektrowni pracujących w kaskadzie.

Wyżej wymienione analizy zostały wykorzystane przy opracowaniu modelu matematycznego testowej elektrowni wodnej oraz testowej kaskady elektrowni wodnych. Przeprowadzone symulacje numeryczne dotyczyły zarówno samodzielnie działającej siłowni, jak i kaskady złożonej z dwóch identycznych obiektów tego typu. Stwierdzono, że w zależności od przyjętego planu pracy siłowni możliwe jest wykorzystanie jej jako elektrowni pracującej zarówno w podstawie, jak i w szczycie obciążenia systemu elektroenergetycznego. Ponadto nawet pojedyncza elektrownia posiada stosunkowo duże możliwości reagowania na zmiany zachodzące w systemie - zarówno te dotyczące wzrostu obciążenia, jak i spadku mocy oddawanej przez sąsiednie elektrownie. Możliwości te znacznie wzrastają w przypadku zbudowania na danym cieku kolejnej siłowni. Kaskada zbiornikowych elektrowni wodnych ma dużo większą zdolność do magazynowania energii i oddawania jej w odpowiednim czasie. Dodatkowo istnienie drugiej elektrowni wyposażonej w zbiornik wyrównawczy pozwala na znaczne zmniejszenie amplitudy przepływów w rzece poniżej kaskady, co zredukuje negatywny wpływ kaskady na środowisko.

SŁOWA KLUCZOWE: małe elektrownie wodne, turbiny wodne, kaskada elektrowni wodnych, odnawialne źródła energii 